\title{
HOMOGRAFIA WYRAZÓW ROSYJSKICH O HOMONIMICZNYCH FORMACH PODSTAWOWYCH
}

\author{
JERZY KALISZAN
}

Język rosyjski charakteryzuje się ogromnym bogactwem zjawisk tzw. homonimii graficznej, czyli homografii, przejawiającej się w relacjach pomiędzy jednostkami wyrazowymi o identycznej pisowni, lecz różnej wymowie i znaczeniu. Podstawową masę homografów, liczącą dziesiątki tysięcy szeregów, stanowią homografy akcentuacyjne, tj. takie, które różnią się od siebie miejscem akcentu wyrazowego, np. мука 'męka' - мука 'mąka', головы (D. lp. rzecz. голова 'głowa') - головы (М. і В. lm. rzecz. голова), мою (1. os. lp. czas. мыть) - мою (B. lp. r. ż. zaimka мой 'mój'), косит (3. os. lp. czas. косить I 'kosić') - косит (3. os. lp. czas. косить II 'zezować'), дорога 'trasa, szlak' - дорога (forma krótka r. ż. przym. дорогой 'drogi, cenny'). Inne przypadki homografii są relatywnie rzadkie i znajdują odzwierciedlenie w szeregach typu конецно [kan'éšnə] 'oczywiście' - конецно [kan'é č'nə] (forma krótka r. n. rzecz. конечный 'skończony; końcowy; ostateczny',

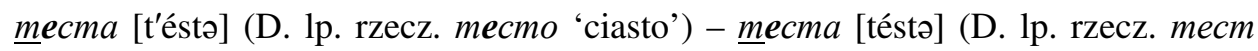
'test'), az̨a [agá] 'tytuł wojskowy w sułtańskiej Turcji' - aza [ahá] 'wykrzyknik', gdzie człony opozycji homograficznej mają identyczny akcent, lecz różnią się od siebie wymową tego samego grafemu spółgłoskowego. Jeszcze rzadsze są sytuacje, gdy komponenty opozycji homograficznej różnią się zarówno artykulacją tego samego grafemu spółgłoskowego, jak i miejscem akcentu wyrazowego, np. mupe [r'] (Ms. lp. rzecz. mup 'strzelnica') - mupe [r] 'myślnik', кapame [t] 'sztuka walki' карате [t'] (Ms. lp. rzecz. kapam 'karat - jednostka masy używana w jubilerstwie').

Celem niniejszego artykułu jest analiza jednego z obszarów rosyjskiej homografii akcentuacyjnej, a mianowicie homografii form wyrazów o homonimicznych for- 
mach podstawowych (słownikowych). Ten rodzaj graficznych utożsamień wyrazów znajduje odzwierciedlenie w sferze dwóch części mowy - rzeczownika i czasownika. Według informacji zawartych w słowniku gramatycznym Aleksandra Zalizniaka (Зализняк, 2008) we współczesnej ruszczyźnie występuje ponad 40 par mianownikowych homonimów rzeczownikowych i ponad 60 par bezokolicznikowych homonimów czasownikowych zdolnych do kreowania szeregów homograficznych. Są to odpowiednio pary typu винт I 'gra w karty' - винт II 'śruba; śmigło', клуб I 'klub' - клуб II 'kłąb (dymu itp.)', тельие I zdrobniale тело 'ciało' - тельце II 'krwinka' oraz pary typu косить I 'kosić' - косить II 'zezować', погрузить I 'załadować' погрузить II 'zanurzyć; pogrążyć', слепить I 'zlepić' - слепить II 'oślepiać'.

Zacznijmy od analizy potencjału homograficznego rzeczowników homonimicznych $w$ formie podstawowej. Ilość relacji homograficznych generowanych przez daną parę homonimów słownikowych jest uzależniona zasadniczo od dwóch czynników: od typu akcentuacyjnego każdego z homonimów oraz od tego, czy posiadają one jeden czy oba paradygmaty liczbowe.

Na przykład rzeczowniki винт I 'gra w karty' - винт II 'śruba; śmigło' mają wspólną tylko liczbę pojedynczą, gdyż z przyczyn semantycznych wyraz винт I nie występuje w liczbie mnogiej. W tej sytuacji formy homograficzne możliwe są tylko w paradygmacie liczby pojedynczej, gdzie stanowią wynik zróżnicowania akcentowego rzeczowników (pierwszy ma akcent stały na temacie, drugi - akcent stały na końcówce), por.: винта - винта, винту - винту, винтом - винтом, винте винте. Z kolei rzeczowniki клуб I 'klub' - клуб II 'kłąb', тельце I zdrobnienie od тело 'ciało' - тельие II 'krwinka' posiadają pełny paradygmat liczbowy, ale w związku ze stałością akcentu w pierwszych członach opozycji homonimicznych (akcent na temacie w liczbie pojedynczej i mnogiej) i ruchomością akcentu w drugich członach (przejściem $\mathrm{z}$ tematu w liczbie pojedynczej na końcówkę w liczbie mnogiej) homograficzność tych rzeczowników obejmuje tylko pluralne formy, por.: клубы (М. і В. lm.) - клубы (М. і В. lm.), клубов (D. lm.) - клубов (D. lm.), клубам (С. $\operatorname{lm}$.$) - клубам (С. \operatorname{lm}$.$) , клубами (N. \operatorname{lm}$.$) - клубами (N. lm.), клубах$

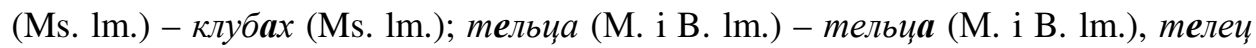
(D. $1 \mathrm{~m}$.) - телец (D. $1 \mathrm{~m}$.$) , тельцам (С. 1 \mathrm{~m}$.) - тельцам (С. $1 \mathrm{~m}$.$) , тельцами (N. 1 \mathrm{~m}$. - тельцами (N. lm.), тельцах (Ms. Im.) - тельиах (Ms. lm.). Zdarza się, że ze względu na specyfikę akcentu rzeczowniki homonimiczne posiadające obie liczby gramatyczne stają się homografami tylko w znikomej części równoległych form, a niekiedy zaledwie w jednej formie. Mowa tu na przykład o leksemach средa I 'środa' - сред $\boldsymbol{a}$ II 'środowisko', które są sobie akcentowo przeciwstawione tylko w B. lp. oraz C., N. i Ms. lm., por. среду - среду, средам - средам, средами средами, средах - средах; czy leksemach пол I 'podłoga' - пол II 'płeć', homograficznych tylko w M. і В. Im., por. поль - поль, oraz z drugiej strony o leksemach голова I 'głowa (część ciała)' - голова II 'naczelnik, przełożony', косa 
I 'kosa (narzędzie rolnicze)' - кoca II 'warkocz', różniących się miejscem akcentu jedynie w B. lp., por. голову - голову, косу - косу.

Z kolei maksymalne stopnie homograficzności osiągają te rzeczownikowe homonimy słownikowe, $\mathrm{z}$ których jeden posiada stały akcent na temacie w obu liczbach, drugi zaś stały akcent na końcówce w obu liczbach. Należą do nich m.in. diady rzeczownikowe typu вираж I 'roztwór fotograficzny' - вираж II 'ostry zakręt', myз I 'szalupa' - myз II 'as, ważna osoba; tuz', бунm I 'bunt' - бунm II 'paczka, bela, zwój', zурm I 'element architektoniczny' - zурm II 'stado', щyp I 'antenat' щyp II 'gatunek ptaka'. Dwie pierwsze z nich generują po 9 szeregów homograficznych, dwie następne - po 10 szeregów, ostatnia - aż 11 szeregów, por.: виража виража, виражу - виражу, вираже - вираже, виражи (М. $\mathrm{lm}$.) - виражи (M. Im.), виражей - виражей, виражам - виражам, виражи (B. $1 \mathrm{~m}$.$) - виражи$ (B. lm.), виражами - виражами, виражсах - виражах; туза (D. lp.) - туза (D. lp.), тузу - тузу, тузом - тузом, тузе - тузе и тузы - тузы, тузов (D. lm.) - тузов (D. lm.), тузам - тузам, тузами - тузами, тузах - тузах; бунта бунта, бунту - бунту, бунтом - бунтом, бунте - бунте и бунты (М. lm.) бунты (М. lm.), бунтов - бунтов, бунтам - бунтам, бунты (В. $1 \mathrm{~m}$.) - бунты (B. $\operatorname{lm}$.), бунтами - бунтами, бунтах - бунтах; гурта - гурта, гурту - гурту, гуртом - гуртом, гурте - гурте и гурты (М. lm.) - гурты (М. lm.), гуртов гуртов, гуртам - гуртам, гурты (В. $1 \mathrm{~m}$.) - гурты (B. $1 \mathrm{~m}$.), гуртами - гуртами, гуртах - гуртах; щура (D. lp.) - щура (D. lp.), щуру - щуру, щура (B. lp.) щура (B. lp.), цуром - щуром, цуре - щуре и цуры - щуры, щуров (D. lm.) - щуров (D. lm.), цурам - щурам, щуров (B. $1 \mathrm{~m}$.) - щуров (B. $\mathrm{lm}$.), цурами щурами, цурах - щурах.

Z semantycznego punktu widzenia zademonstrowane wyżej pary homograficzne reprezentują tzw. homografię leksykalną (лексическая омография: Колесников, 1968; Мельникова, 1974; Мельникова, 1988; Петренко, 1987; Емельянова, 2003 : 263-267), bowiem komponenty tych par różnią się wyłącznie znaczeniem leksykalnym (reprezentują różne leksemy), są natomiast identyczne pod względem gramatycznym. Homografii leksykalnej można przeciwstawić homografię leksykalno-gramatyczną (лексико-грамматическая омография: Колесников, 1968; Мельникова, 1974; Мельникова, 1988; Петренко, 1987; Емельянова, 2003: 263-267), czyli homografię nierównoznacznych (nieadekwatnych) form dwóch określonych leksemów.

W wypadku rzeczowników o homonimicznych formach podstawowych homografia leksykalno-gramatyczna widoczna jest w takich parach wyrazowych jak бopy (C. lp. rzecz. бор I 'pierwiastek chemiczny' - (в) бору (L. rzecz. бор II 'bór'), виражи (M. $1 \mathrm{~m}$.) - виражи (В. $1 \mathrm{~m}$.), виражи (В. $\operatorname{lm}$.) - виражи (M. $1 \mathrm{~m}$.), ордена (D. lp. rzecz. орден I 'zakon; organizacja') - ордена (M. Im. rzecz. орден II 'order') і ордена (D. lp. rzecz. орден I) - ордена (B. lm. rzecz. орден II), гряды (D. lp. rzecz. гряда I 'łańcuch górski') - гряды (M. lm. rzecz. гряда II 'grządka') і гряды (D. lp. rzecz. гряда I) - гряды (B. lm. rzecz. гряда II). 
Homografia leksykalno-gramatyczna obejmuje tylko niektóre formy homonimów rzeczownikowych, w odróżnieniu od homografii określanej mianem leksykalnej, która w większości wypadków ma charakter seryjny.

Zarówno homografia czysto leksykalna, jak i homografia leksykalno-gramatyczna wyrazów o homonimicznych formach słownikowych (podstawowych) znajduje jaskrawe odzwierciedlenie również w sferze czasownika. Oba typy homografii występują wyłącznie pomiędzy dwoma określonymi czasownikami na -umb, takimi jak валить I 'obalać, przewracać; rzucać' - валить II 'walić, buchać (o śniegu, dymie)', косить I 'kosić' - косить II 'zezować', просветить I 'prześwietlić' - просветить II 'oświecić, przekazać wiedzę', растворить I 'otworzyć, rozewrzeć' - растворить II 'rozpuścić w cieczy', расточить I 'wytoczyć, roztoczyć' - расточить II 'roztrwonić, zmarnować', погрузиться I 'zostać załadowanym' - погрузиться II 'zanurzyć się; pogrążyć się', скопить I 'zaoszczędzić' скопить II 'kastrować', слепить I 'zlepić' - слепить II 'oślepiać', сволочить I 'ściągnąć, zwlec' - сволочить II 'wyzywać, przeklinać' itp.

Homografia leksykalna czasowników homonimicznych w formach bezokolicznikowych występuje wyłącznie w parach czasowników równoaspektowych i powstaje dzięki temu, że w paradygmacie czasu teraźniejszego lub przyszłego prostego w jednym z tych czasowników akcent pada na temat, w drugim zaś - na końcówkę (różnice akcentowe nie dotyczą jedynie 1. os. lp). W rezultacie pary czasownikowe, o których mowa, kreują regularnie po 5 diad homograficznych, por.: валишь валишь, валит - валит, валим - валим, валите - валите, валят - валят; косишь - косишь, косит - косит, косим - косим, косите - косите, косят - косят; просветишь - просветишь, просветит - просветит, просветим - просветим, просветите - просветите, просветят - просветят; растворишь - растворишь, растворит - растворит, растворим - растворим, растворите - растворите, растворят - растворят; расточишь - расточишь, расточит - расточит, расточим - расточим, расточите - расточите, расточат - расточат; погрузишься - погрузишься, погрузится - погрузится, погрузимся - погрузимся, погрузитесь - погрузитесь, погрузятся - погрузятся.

Z kolei homografia leksykalno-gramatyczna badanych par czasownikowych, czyli homografia nierównoznacznych form fleksyjnych dwóch czasowników, przejawia się z jednej strony w opozycjach form czasu przyszłego prostego i form czasu teraźniejszego czasowników różnoaspektowych, z drugiej zaś w opozycjach formy 2. os. $1 \mathrm{~m}$. czasu teraźniejszego lub przyszłego prostego i formy trybu rozkazującego czasowników równo- lub różnoaspektowych. W pierwszym przypadku chodzi o utożsamienia graficzne typu слепишь - слепишь, слепит - слепит, слепим слепим, слепите - слепите, слепят - слепят; скопишь - скопишь, скопит - скопит, скопим - скопим, скопите - скопите, скопят - скопят; сволочишь сволочишь, сволочит - сволочит, сволочим - сволочим, сволочите - сволочите, сволочат - сволочат. Drugi przypadek ilustrują takie pary homograficzne 
jak валите (валить I) - валите (валить II), косите (косить I) - косите (косить II), просветите (просветить I) - просветите (просветить II), растворите (растворить I) - растворите (растворить II), погрузитесь (погрузиться I) - погрузитесь (погрузиться II), скопите (скопить I) - скопите (скопить II), слепите (слепить I) - слепите (слепить II) itp.

Na podstawie przeprowadzonej analizy par rzeczowników i czasowników rosyjskich posiadających homonimiczne formy słownikowe można dojść do wniosku, że pary te stanowią bogate źródło zjawisk homograficznych we współczesnej ruszczyźnie. W sferze badanych rzeczowników można wyodrębnić co najmniej 200 szeregów homografów leksykalnych i ponad 100 szeregów homografów leksykalno-gramatycznych, zaś w sferze czasowników - odpowiednio około 300 i 80 szeregów homograficznych. Opis tego typu faktów, ilustrujących jeden z przejawów niejednoznaczności i asymetrii znaku językowego i łączących w sobie elementy czterech płaszczyzn - leksykalnej, gramatycznej, fonetycznej i graficznej, ma obok wartości teoretycznej istotny sens praktyczny i może być z powodzeniem wykorzystany w preparacji tekstów do nauki języka rosyjskiego jako obcego.

\section{Bibliografia}

Емельянова, О.Н. 2003. Омонимия и смежные явления. W zbiorze: Кожина, M.H. (red.). Стилистический энциклопедический словарь русского языка. Москва: Флинта: Наука.

Зализняк, А.А. 2008. Грамматический словарь русского языка. Москва: АСТ-ПРЕСС КНИГА.

Колесников, Н.П. 1968. Система словесных омонимов в русском языке. W zbiorze: ХІІ научная сессия филологического факультета. План работы и тезисы докладов. Тбилиси: Тбилисский государственный университет.

Мельникова, А.И. 1974. „К вопросу о русских омографах”. Русский язык в школе 4. 80-84.

Мельникова, А.И. 1988. „Пути возникновения и развития омографии в русском языке”. Русский язык в школе 4. 73-78.

Петренко, М.Г. 1987. Явление омографии в современном русском языке. Автореф. дисс. канд. филол. наук. Одесса: Одесский государственный университет им. И.И. Мечникова. 